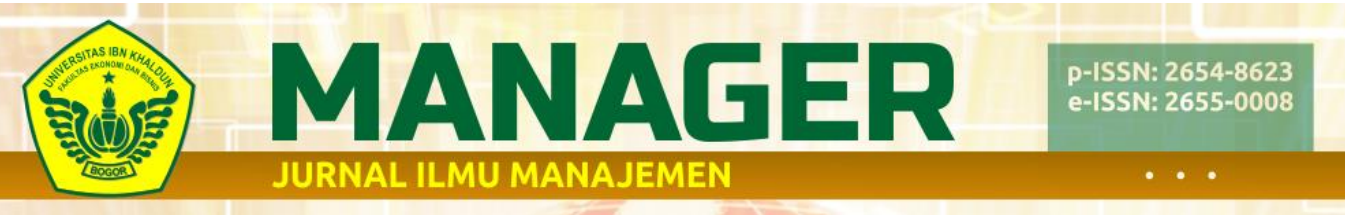

Vol. 2, No. 2, Mei 2019, Hal 11-20@(๑) http://ejournal.uikabogor.ac.id/index.php/Manager/index

\title{
PENGARUH KEPUASAN KERJA DAN KOMUNIKASI TERHADAP KINERJA KARYAWAN
}

\section{Galih Arisca, Muhamad Azis Firdaus dan Rachmatullaily Tinakartika Rinda ariscagalih@gmail.com, azisfirdaus@uika-bogor.ac.id,lailyrinda@yahoo.com Fakultas Ekonomi dan Bisnis Universitas Ibn Khaldun Bogor, Indonesia}

\begin{abstract}
Abstrak
Penelitian ini bertujuan untuk Kepuasan Kerja dan Kesiapan Karyawan yang dilakukan oleh karyawan Bank BJB Cabang Kota Depok. Metode survei dalam penelitian ini menggunakan data primer yang diperoleh dari kuesioner dan data sekunder dari resmi Bank BJB Cabang Kota Depok di internet. Sampel dalam penelitian ini adalah 50 responden menggunakan teknik Quota Sampling. Metode penelitian menggunakan uji validitas dan reliabilitas, koefisien determinasi, regresi linier sederhana, berganda, uji normalitas dengan uji hipotesis simultan $(\mathrm{F})$ dan parsial $(\mathrm{T})$ dengan mengolah menggunakan aplikasi komputer. Hasil penelitian ini menunjukkan bahwa Kepuasan Kerja dan Komunikasi secara simultan berpengaruh positif terhadap Kinerja Karyawan.
\end{abstract}

Kata Kunci: Kepuasan Kerja, Komunikasi, Kinerja Karyawan

\begin{abstract}
This study aims to Job Satisfaction and Employee Readiness conducted by employees of the BJB Bank Branch of Depok City. The survey method in this study used the primary data obtained from questionnaires and secondary data from the official BJB Bank Branch of Depok City on the internet. The sample in this research is 50 respondents using Quota Sampling technique. The research method uses the test of validity and reliability, coefficient of determination, simple linear regression, multiple, normality test to simultaneous hypothesis test $(F)$ and partial $(T)$ by processing using computer applications. The results of this study show that Job Satisfaction and Communication are simultaneously have a positive effect on Employee Performance.
\end{abstract}




\section{Keywords: Job Satisfaction, Communication, Employee Performance}

\section{Pendahuluan}

Di dalam sebuah organisasi, manusia merupakan salah satu aspek sumber daya yang sangat penting, karena suatu organisasi tidak akan bisa berjalan apabila tidak ada manusia. Seiring berkembangnya zaman, banyak organisasi yang mengurangi sumber daya manusia di karenakan teknologi mesin yang saat ini sudah semakin canggih dan dapat menggantikan pekerjaan manusia. Hal ini di karenakan penggunaan mesin lebih efektif dan efisien dibandingkan dengan tenaga manusia. Namun, disisi lain manusia tidak dapat tergantikan sepenuhnya oleh mesin karena apabila tidak ada manusia, mesin pun tidak dapat beroperasi.

Pentingnya peran manusia tidak lepas dari usaha perusahaan dalam mengelola SDM tersebut dimana pengelolaan yang baik akan menghasilkan SDM yang berkualitas dalam menjalankan pekerjaannya. Pengelolaan merupakan salah satu fungsi dari manajemen yang tidak bisa dihilangkan. Jika suatu perusahaan tidak bisa mengelola SDM dengan baik maka perusahaan tersebut tidak akan mengalami kemajuan, karena indikator kemajuan suatu perusahaan salah satunya dilihat dari kualitas SDM nya sebagai penopang perusahaan tersebut.

Untuk menciptakan kualitas SDM yang baik diperlukan kepuasan kerja yang dirasakan oleh karyawan, karena kepuasan kerja yang didapatkan seseorang dapat menjadi tolak ukur seberapa produktifnya karyawan tersebut . Kepuasan kerja dapat dikatakan merupakan hal yang bersifat individu. Dimana tingkat kepuasan yang dimiliki setiap individu berbeda-beda sesuai dengan sistem nilai-nilai yang berlaku pada dirinya. Hal ini disebabkan karena adanya perbedaan pada masingmasing individu. Semakin banyak aspek-aspek dalam pekerjaan yang sesuai dengan keinginan individu tersebut, maka akan semakin tinggi pula tingkat kepuasan yang dirasakannya. Sebaliknya, semakin sedikit aspek-aspek dalam pekerjaan yang sesuai dengan keinginan individu, maka semakin rendah tingkat kepuasan yang dirasakan.

Komunikasi dalam suatu organisasi atau perusahaan juga sangat penting dalam menciptakan SDM yang berkualitas karena jika di dalam suatu organisasi atau perusahaan tidak tercipta jaringan komunikasi yang baik antara anggota dengan anggota maupun anggota dengan pimpinan, maka akan terjadi miskomunikasi yang dapat menimbulkan kekacauan atau hambatan dalam pencapaian tujuan perusahaan. Hal ini sangat penting karena masih banyak kasus di dalam suatu perusahaan yang didalamnya sering terjadi miskomunikasi antar karyawan maupun antara atasan dan bawahan. Ada beberapa jenis 
komunikasi yang biasanya digunakan didalam perusahaan, yaitu 1) komunikasi verbal , 2) komunikasi non verbal, 3) komunikasi formal, dan 4) komunikasi informal

Kualitas SDM yang baik bisa dilihat dari kinerja SDM itu sendiri. Kinerja adalah sesuatu yang ditampilkan oleh seseorang atau suatu proses yang berkaitan dengan tugas kerja yang ditetapkan. Kinerja bukan ujung terakhir dari serangkaian sebuah proses kerja tetapi tampilan keseluruhan yang dimulai dari unsur kegiatan input, proses, output dan bahkan outcome. Keempat elemen itu merupakan satu kesatuan yang dapat menjadi tolak ukur perusahaan dalam menilai kinerja karyawannya.

\section{Metode Penelitian}

Ruang lingkup penelitian yang diambil adalah pengaruh kepuasan kerja dan komunikasi terhadap kinerja karyawan. Hal ini dilakukan untuk mengetahui seberapa besar pengaruh kepuasan kerja terhadap kinerja karyawan, komunikasi terhadap kinerja karyawan serta pengaruh kepuasan kerja dan komunikasi terhadap kinerja karyawan. Penelitian dilakukan dengan sampel karyawan bank BJB cabang kota Depok sebanyak 50 responden dan penelitian dilakukan pada tanggal 6 Agustus sampai 10 Agustus 2018.

\section{Hipotesis}

Hipotesis ialah jawaban sementara terhadap tujuan penelitian yang diturunkan dari kerangka pemikiran yang telah dibuat. Hipotesis yang digunakan dalam penelitian ini menggunakan hipotesis asosiatif adalah jawaban sementara terhadap masalah asosiatif, yaitu yang menanyakan hubungan antara dua variabel atau lebih.

$\mathrm{Ho}_{1}=$ Tidak terdapat pengaruh yang signifikan antara kepuasan kerja terhadap kinerja

$\mathrm{Ha}_{1}=$ Terdapat pengaruh yang signifikan antara kepuasan kerja terhadap kinerja

$\mathrm{Ho}_{2}=$ Tidak terdapat pengaruh yang signifikan antara komunikasi terhadap kinerja

$\mathrm{Ha}_{2}=$ Terdapat pengaruh yang signifikan antara komunikasi terhadap kinerja

$\mathrm{Ho}_{3}=$ Tidak terdapat pengaruh yang signifikan antara kepuasan kerja dan komunikasi terhadap kinerja

$\mathrm{Ha}_{3}=$ Terdapat pengaruh yang signifikan antara kepuasan kejra dan komunikasi terhadap kinerja

\section{Instrumen Pengumpulan Data}

Metode pengumpulan data yang dipergunakan dalam penelitian ini dengan menyebarkan kuesioner sebanyak 50 kuesioner kepada karyawan Bank BJB cabang kota Depok yang kemudian dikumpulkan dan diolah menggunakan aplikasi komputer. Variabel Kepuasan Kerja diukur dengan 10 instrumen pertanyaan, 10 instrumen pertanyaan untuk Komunikasi dan 10 instrumen pertanyaan Kinerja Karyawan. 
Jawaban atas setiap pertanyaan diisi sesuai skala Likert 1-5 dan diberi skor sebagai berikut. Skor/nilai 1 (klasifikasi 1,00-1,79) menunjukan respon STP (sangat tidak puas) untuk variabel Kepuasan, STB (sangat tidak baik) unutk variabel Komunikasi dan STS (sangat tidak setuju) untuk variabel Kinerja. Skor/nilai 2 (klasifikasi 1,80-2,59) menunjukan respon TS (tidak puas) untuk variabel Kepuasan, TB (tidak baik) untuk variabel Komunikasi, dan TS (tidak setuju) untuk variabel Kinerja. Skor/nilai 3 (klasifikasi 2,60-3,39) menunjukan respon $\mathrm{CP}$ (cukup puas) untuk variabel Kepuasan, CB (cukup baik) untuk variabel Komunikasi, dan N (netral) untuk variabel Kinerja. Skor/nilai 4 (klasifikasi 3,40-4,19) menunjukan respon $\mathrm{P}$ (puas) untuk variabel Kepuasan, B (baik) untuk variabel Komunikasi, dan S (setuju) untuk variabel Kinerja. Skor/nilai 5 (klasifikasi 4,20-5,00) menunjukan respon SP (sangat puas) untuk variabel Kepuasan, SB (sangat baik) untuk variabel Komunikasi, dan SS (sangat setuju) untuk variabel Kinerja.

\section{Uji Instrumen Penelitian}

Untuk menguji instrumen penelitian digunakan uji validitas dan realibilitas. Pengujian validitas dengan menggunakan teknik korelasi "Pearson Product Moment" dengan tingkat kepercayaan $95 \%(\alpha=0,05)$ dilakukan dengan cara mengkorelasikan skor masingmasing item dengan skor totalnya.
Sedangkan uji reabilitas merupakan ukuran suatu kestabilan dan konsistensi responden dalam menjawab hal yang berkaitan dengan kontruk-kontruk pertanyaan yang merupakan dimensi suatu variabel dan disusun dalam suatu bentuk kuisioner. Uji reabilitas menggunakan rumus Cronbach Alpha dapat dilakukan secara bersama-sama terhadap seluruh butir pertanyaan. Jika nilai Alpha > 0,60 maka dapat dikatakan reliabel. Selain uji validitas dan reliabilitas, ada uji asumsi klasik (uji normalitas, uji homogenitas, dan uji reliabilitas), analisis inferentif (korelasi, regresi berganda, koefisien determinasi, uji T dan uji F).

\section{Tinjauan Pustaka.}

Kepuasan kerja adalah suatu sikap karyawan terhadap pekerjaan yang berhubungan dengan situasi kerja, kerja sama antar karyawan, imbalan yang diterima dalam kerja, dan halhal yang menyangkut faktor fisik dan psikologis (Sutrisno,2009:74)

Variabel-variabel Kepuasan Kerja
Menurut pendapat Keith Davis (Dalam Mangkunegara, 2015:117119) yang mengemukakan bahwa:

"job statisfaction is related to a number of major employee variables, such as turnover, absences, age, occupation, and size of the organization in which an employee works".

1.Turnover

Kepuasan kerja lebih tinggi dihubungkan dengan turnover 
pegawai yang rendah. Sedangkan pegawai-pegawai yang kurang puas biasanya turnover nya lebih tinggi.

2.Tingkat Ketidakhadiran (absen) Kerja

Pegawai-pegawai yang kurang puas cenderung tingkat ketidakhadirannya (absen) tinggi. Mereka sering tidak hadir kerja dengan alasan yang tidak logis dan subjektif.

\section{Umur}

Ada kecenderungan pegawai yang lebih tua lebih merasa puas daripada pegawai yang berumur relatif muda. Hal ini diasumsikan bahwa pegawai yang tua lebih berpengalaman menyesuaikan diri dengan lingkungan perkerjaan. Sedangkan pegawai usia muda biasanya mempunyai harapan yang ideal tentang dunia kerjanya, sehingga apabila antara harapan dengan reallita kerja terdapat kesenjangan atau ketidakseimbangan dapat menyebabkan mereka menjadi tidak puas.

4.Tingkat Pekerjaan

Pegawai-pegawai yang menduduki tingkat pekerjaan yang lebih tinggi cenderung lebih puas daripada pegawai yang menduduki tingkat pekerjaan yang lebih rendah. Pegawai-pegawai yang tingkat pekerjaannya lebih tinggi menunjukan kemampuan kerja yang baik dan aktif dalam mengemukakan ide-ide serta kreatif dalam bekerja.

5.Ukuran Organisasi Perusahaan

Ukuran organisasi perusahaan dapat mempengaruhi kepuasan pegawai. Hal ini karena besar kecil suatu perusahaan berhubungan pula

dengan koordinasi, komunikasi, dan partisipasi pegawai.

Komunikasi adalah proses pemindahan pengertian dalam bentuk gagasan atau informasi dari seseorang ke orang lain (Handoko,2015:270). Definisi lain dari komunikasi adalah penyampaian dan pemahaman suatu maksud yang terjadi apabila informasi berhasil disampaikan.

(Munandar,dkk,2014:136)

Proses komunikasi merupakan serangkaian tahapan antara sumber atau pengirim (sources atau sender) dan penerima (receiver) yang akan menghasilkan suatu transfer pemahaman mengenai sesuatu yang berarti, yaitu pesan. Pesan adalah sesuatu yang hendak dikomunikasikan.

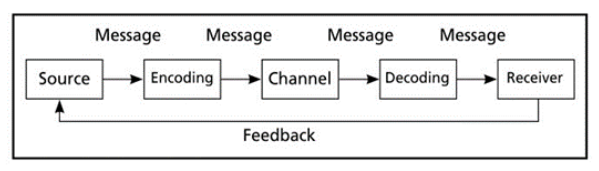

Sumber: Robbins, S.P. (2001)

Gambar 2.2

Proses Komunikasi

Performance adalah hasil kerja yang dapat dicapai oleh seseorang atau sekelompok orang dalam suatu organisasi, sesuai dengan wewenang dan tanggung jawab masing-masing, dalam rangka upaya mencapai tujuan organisasi bersangkutan secara legal, tidak melanggar hukum dan sesuai dengan moral maupun etika (Prawirosentono,2008:2). Menurut Bangun (2012:234), standar pekerjaan dapat ditentukan dari isi 
suatu pekerjaan, dapat dijadikan sebagai dasar penilaian pekerjaan, yaitu:

1.Jumlah Pekerjaan

Dimensi ini menunjukan jumlah pekerjaan yang dihasilkan individu atau kelompok sebagai persyaratan yang menjadi standar pekerjaan.

\section{Kualitas Pekerjaan}

Setiap karyawan dalam perusahaan harus memenuhi persyaratan tertentu untuk dapat menghasilkan pekerjaan sesuai kualitas yang dituntun suatu pekerjaan tertentu. Setiap pekerjaan mempunyai standar kualitas tertentu yang harus disesuaikan oleh karyawan untuk mengerjakan sesuai ketentuan.

\section{Kesempatan Waktu}

Setiap pekerjaan memiliki karakteristik yang berbeda, untuk jenis pekerjaan tertentu harus dikerjakan tepat waktu, karena memiliki ketergantungan atas pekerjaan lainnya. Jadi jika pekerjaan pada suatu bagian tertentu tidak selesai tepat waktu akan menghambat pekerjaan pada bagian lainnya. Sehingga mempengaruhi jumlah dan kualitas hasil kerja.

4.Kehadiran

Suatu jenis pekerjaan tertentu menuntuk kehadiran karyawan dalam mengerjakan sesuai waktu yang ditentukan.

5.Kemampuan Kerjasama

Kerjasama berkaitan dengan pertimbangan kemampuan untuk bekerjasama dengan orang lain.

\section{Hasil dan Pembahasan}

Penelitian ini menggunakan metode penelitian kuantitatif yaitu data yang berbentuk angka atau data kualitatif yang di angkakan (scoring). Variabel independen dari penelitian ini adalah Kepuasan Kerja $\left(\mathrm{X}_{1}\right)$ dan Komunikasi $\left(\mathrm{X}_{2}\right)$ sedangkan variabel dependennya yaitu Kinerja Karyawan (Y).

\section{Uji Validitas dan Reliabilitas}

Untuk pengujian validitas didapatkan hasil bahwa setiap variabel yaitu Kepuasan Kerja, Komunikasi, dan Kinerja Karyawan memiliki $r_{\text {hitung }}>r_{\text {tabel }}(0,273)$ sehingga dapat dikatakan bahwa kesuluruhan item variabel penelitian Kepuasan Kerja, Komunikasi, dan Kinerja adalah valid untuk digunakan sebagai instrumen dalam penelitian atau pertanyaan-pertanyaan yang diajukan dapat digunakan untuk mengukur variabel yang diteliti.

Sedangkan pengujian Reliabilitas didapatkan hasil pengujian setiap variabel yaitu Kepuasan Kerja, Komunikasi, dan Kinerja Karyawan memiliki nilai Cronbach's Alpha > 0,60 sehingga dapat dikatakan bahwa seluruh item pertanyaan reliabel dan dapat diterima.

\section{Uji Asumsi Klasik}

Uji asumsi klasik dalam penelitian ini meliputi uji normalitas

\section{Uji Normalitas}

Uji normalitas merupakan pengujian dengan cara membandingkan antara data yang kita miliki dengan data berdistribusi 
normal yang memiliki mean dan standar deviasi yang sama dengan data kita (Sujarweni,2014:102).

Berdasarkan hasil olahan menggunakan aplikasi komputer didapatkan seluruh data variabel berdistribusi normal dengan hasil penelitian Asymp.Sig $\mathrm{X}_{1}$ (Kepuasan Kerja) > 0,05 yaitu sebesar 0,078, Asymp.Sig $\mathrm{X}_{2}$ (Komunikasi) > 0,05 yaitu sebesar 0,197, Dan Asymp.Sig $\mathrm{Y}>0,05$ yaitu sebesar 0,298.

\section{Uji Homogenitas}

Uji homogenitas dilakukan untuk mengetahui apakah data dalam variabel $\mathrm{x}$ dan y bersifat homogeny atau tidak. Dalam penelitian ini data diuji homogenitasnya dengan menggunakan metode One- Way ANOVA yang diolah dengan aplikasi komputer dan mendapatkan hasil signifikansi variabel Kinerja Karyawan (Y) berdasarkan variabel Kepuasan Kerja $\left(X_{1}\right)=0,000<0,05$, maka dapat disimpulkan bahwa data variabel Kinerja Karyawan (Y) berdasarkan variabel Kepuasan Kerja $\left(\mathrm{X}_{1}\right)$ mempunyai variabel yang tidak sama atau tidak homogen. Berbeda dengan hasil signifikansi variabel Kinerja Karyawan (Y) berdasarkan variabel Komunikasi $\left(\mathrm{X}_{2}\right)$ yaitu $0,762>0,05$, maka dapat disimpulkan bahwa data variabel Kinerja Karyawan (Y) berdasarkan variabel Komunikasi $\left(\mathrm{X}_{2}\right)$ mempunyai variabel yang sama atau homogen.

\section{Uji Linieritas}

Uji linieritas bertujuan untuk mengetahui apakah dua variabel mempunyai hubungan yang linier atau tidak secara signifikan. Hasil dari pengujian linieritas untuk variabel Kinerja Karyawan (Y) terhadap Kepuasan Kerja $\left(\mathrm{X}_{1}\right)$ adalah $F_{\text {hitung }}=1,30$ sedangkan $F_{\text {tabel }}=4,03$ dengan demikian $\mathrm{F}$ hitung $=1,30<$ $\mathrm{F}$ tabel $=4,03$, maka dapat disimpulkan bahwa terdapat hubungan linier secara signifikan antara variabel Kepuasan Kerja $\left(\mathrm{X}_{1}\right)$ dengan Kinerja Karyawan (Y). Untuk uji linieritas variabel Kinerja Karyawan (Y) terhadap Komunikasi $\left(\mathrm{X}_{2}\right)$ didapatkan hasil $\mathrm{F}_{\text {hitung }}=1,187$ sedangkan $F_{\text {tabel }}=4,03$ dengan demikian $\mathrm{F}$ hitung $=1,187<\mathrm{F}$ tabel $=4,03$, maka dapat disimpulkan bahwa terdapat hubungan linier secara signifikan antara variabel Komunikasi $\left(\mathrm{X}_{2}\right)$ dengan Kinerja Karyawan (Y).

\section{Analisis Inferentif}

\section{Analisis Korelasi}

Analisis ini digunakan untuk mengukur kekuatan hubungan antara dua variabel, dimana jika koefisien korelasi diketemukan tidak sama dengan nol (0), maka terdapat hubungan antara dua variabel. Hasil analisis korelasi variabel Kepuasan Kerja $\left(\mathrm{X}_{1}\right)$ terhadap Kinerja Karyawan (Y) menunjukan $\mathrm{R}=$ 0,614 terletak pada interval $0,60-$ 0,79 (Kuat), hal ini menunjukan bahwa hubungan antara variabel Kepuasan Kerja $\left(\mathrm{X}_{1}\right)$ dan Kinerja Karyawan (Y) adalah Kuat dan positif. Berarti apabila $\mathrm{X}_{1}$ naik maka 
Y juga naik. Hasil analisis korelasi variabel Komunikasi $\left(\mathrm{X}_{2}\right)$ terhadap Kinerja Karyawan (Y) menunjukan $\mathrm{R}=0,243$ terletak pada interval 0,20 - 0,39 (Rendah), hal ini menunjukan bahwa hubungan antara variabel Komunikasi $\left(\mathrm{X}_{2}\right)$ dan Kinerja Karyawan (Y) adalah Rendah dan positif. Berarti apabila $\mathrm{X}_{2}$ naik maka $\mathrm{Y}$ juga naik. Dan yang terakhir analisis korelasi variabel Kepuasan Kerja $\left(\mathrm{X}_{1}\right)$ dan Komunikasi $\left(\mathrm{X}_{2}\right)$ terhadap Kinerja Karyawan (Y) menunjukan menunjukan $\mathrm{R}=0,678$ terletak pada interval $0,60-0,79$ (Kuat), hal ini menunjukan bahwa hubungan antara variabel Kepuasan Kerja $\left(\mathrm{X}_{1}\right)$ dan Komunikasi $\left(\mathrm{X}_{2}\right)$ terhadap Kinerja Karyawan (Y) adalah Kuat dan positif. Berarti apabila $\mathrm{X}_{1}$ dan $\mathrm{X}_{2}$ naik maka $\mathrm{Y}$ juga naik.

\section{Analisis Regresi Berganda}

Regresi yang memiliki variabel dependen dan dua atau lebih variabel independent. Dalam penelitian ini variabel yang diteliti adalah Kepuasan Kerja $\left(\mathrm{X}_{1}\right)$ dan Komunikasi $\left(\mathrm{X}_{2}\right)$ terhadap Kinerja Karyawan (Y) yang menunjukan persamaan regresi sebagai berikut:

$$
Y=10,376+0,490 X_{1}+0,272 X_{2}
$$

Dimana nilai constant (Y) sebesar 10,376 artinya jika variabel Kepuasan Kerja dan Komunikasi bernilai 0 (nol), maka nilai variabel kinerja karyawan (Y) akan berada pada angka 10,376.

\section{Koefisien Determinasi}

Hasil pengujian kefisien determinasi pada variabel Kepuasan
Kerja $\quad\left(\mathrm{X}_{1}\right)$ terhadap Kinerja Karyawan (Y) adalah 0,364 atau $(36,4 \%)$ memberikan arti bahwa besarnya pengaruh Kepuasan Kerja terhadap Kinerja Kayawan sebesar $36,4 \%$ sedangkan sisanya $63,6 \%$ dipengaruhi oleh faktor-faktor lain yang tidak dimasukan dalam penelitian ini. Untuk variabel Komunikas $\left(\mathrm{X}_{2}\right)$ terhadap Kinerja Karyawan (Y) adalah 0,040 atau (4\%) memberikan arti bahwa pengaruh Komunikasi terhadap Kinerja Kayawan sangat kecil hanya sebesar $4 \%$ sedangkan sisanya $96 \%$ dipengaruhi oleh faktor-faktor lain yang tidak dimasukan dalam penelitian ini. Dan pengujian terakhir yaitu variabel Kepuasan Kerja $\left(\mathrm{X}_{1}\right)$ dan Komunikasi $\left(\mathrm{X}_{2}\right)$ terhadap Kinerja Karyawan (Y) sebesar sebesar 0,437 atau $(43,7 \%)$, dengan begitu dapat diartikan bahwa besarnya pengaruh Kepuasan Kerja $\left(\mathrm{X}_{1}\right)$ dan Komunikasi $\left(\mathrm{X}_{2}\right)$ terhadap Kinerja Karyawan (Y) sebesar 43,7\% sedangkan sisanya $\quad 56,3 \%$ dipengaruhi oleh faktor-faktor lain yang tidak dimasukan dalam penelitian ini.

\section{Uji T (Parsial)}

Hasil yang didapatkan berdasarkan pengolahan menggunakan aplikasi komputer menunjukan variabel Kepuasan Kerja $\left(\mathrm{X}_{1}\right)$ terhadap Kinerja Karyawan (Y) mendapatkan hasil $\mathrm{T}_{\text {hitung }}=5,386>\mathrm{T}_{\text {tabel }}=1,677$ maka Ho ditolak (Ha diterima) berarti bahwa terdapat hubungan yang signifikan antara Kepuasan Kerja $\left(\mathrm{X}_{1}\right)$ dan terhadap Kinerja Karyawan (Y). Sedangkan variabel 
Komunikasi $\left(\mathrm{X}_{2}\right)$ terhadap Kinerja Karyawan (Y) mendapatkan hasil $\mathrm{T}$ hitung $=1,737>\mathrm{T}$ tabel $=1,677$ maka Ho ditolak (Ha diterima) berarti bahwa terdapat hubungan yang signifikan antara Komunikasi $\left(\mathrm{X}_{2}\right)$ dan terhadap Kinerja Karyawan (Y).

\section{Uji F (Simultan)}

Hasil uji F (simultan) variabel Kepuasan Kerja $\left(\mathrm{X}_{1}\right)$ dan Komunikasi $\left(\mathrm{X}_{2}\right)$ terhadap Kinerja Karyawan (Y) mendapatkan hasil $\mathrm{F}$ hitung $=19,999>\mathrm{F}_{\text {tabel }}=3,20$ maka Ho ditolak (Ha diterima) berarti bahwa terdapat hubungan yang signifikan antara Kepuasan Kerja $\left(\mathrm{X}_{1}\right)$ dan Komunikasi $\left(\mathrm{X}_{2}\right)$ terhadap Kinerja Karyawan (Y).

\section{Kesimpulan dan Saran Kesimpulan}

Berdasarkan hasil penelitian yang diolah menggunakan aplikasi komputer, dapat ditarik kesimpulan sebagai berikut: 1) Kepuasan kerja berpengaruh positif terhadap kinerja karyawan Bank BJB cabang Kota Depok yang artinya jika seluruh karyawan mendapatkan kepuasan dalam bekerja maka dapat memberikan kotribusi penuh untuk kemajuan Bank BJB cabang Kota Depok, 2) Komunikasi berpengaruh positif terhadap kinerja karyawan Bank BJB cabang Kota Depok yang artinya jika jalinan komunikasi yang terjadi di Bank BJB cabang Kota Depok sangat baik maka tidak akan terdapat kesalahan informasi yang diterima oleh karyawan sehingga karyawan dapat bekerja maksimal, 3)
Kepuasan Kerja dan Komunikasi berpengaruh positif terhadap Kinerja karyawan Bank BJB cabang Kota Depok dimana kedua variabel ini jika didapatkan oleh karyawan akan menghasilkan profit bagi Bank BJB cabang Kota Depok dalam bentuk kinerja SDM nya yang tentunya akan membantu perusahaan dalam mencapai tujuan yang sudah ditetapkan.

\section{Saran}

Berdasarkan hasil penelitian dan kesimpulan yang telah disajikan maka selanjutnya peneliti menyampaikan saran-saran yang kiranya dapat memberikan manfaat pada pihak-pihak yang terkait atas penelitian ini yaitu: 1) Dalam rangka meningkatkan kinerja karyawannya, Bank BJB Cabang Kota Depok perlu memperhatikan kebutuhan para karyawan seperti Kepuasan Kerja. Karena karyawan merupakan aset penting dari sebuah perusahaan, tanpa karyawan perusahaan tidak akan mengalami kemajuan. 2) Perusahaan harus bisa menjalin komunikasi yang baik antara karyawan dengan karyawan, maupun karyawan dengan atasan. Karena komunikasi itu merupakan poin penting dalam mengembangkan kinerja karyawan, jika komunikasi yang terjalin kurang bagus maka dapat mengganggu aktivitas yang terjadi di dalam perusahaan atau sering disebut misskomunikasi. 3) Bagi peneliti selanjutnya, hendaknya untuk mengembangkan penelitian ini dengan menggunakan variabel atau 
indikator yang berbeda sehingga dapat diperoleh informasi yang lebih lengkap tentang faktor-faktor yang mempengaruhi kinerja karyawan.

\section{Daftar Pustaka}

Amir, M. F. (2015). Memahami

Evaluasi Kinerja Karyawan.

Mitra Wacana Media.

Bangun, W. 2012. Manajemen Sumber Daya Manusia. Jakarta: Erlangga

Daryanto, B. (2017). Manajemen Penilaian Kinerja Karyawan. Gava Media.

Handoko, T. H. (2014). Manajemen Personalia dan Sumber Daya Manusia. BPFE-Yogyakarta.

Hasan. (2013). Analisis Data

Penelitian Dengan Statistik. Bumi Aksara.

Mangkunegara, A. P. (2015). Manajemen Sumber Daya Manusia Perusahaan. PT. Remaja Rosdakarya

. Munandar, dkk. 2014. Pengantar Manajemen, Panduan Komprehensif Pengelolaan Organisasi. Bogor: PT Penerbit IPB Press
Prawirosentono, Suyadi. 2008. Manajemen Sumberdaya Manusia, Kebijakan Kinerja Karyawan. Yogyakarta: BPFE-Yogyakarta

Sugiyono. (2015). Statistika Untuk Penelitian. Alfabeta.

Sujarweni, V. W. (2014). Metodologi Penelitian. Pustaka Baru. Sujarweni, Vw. (2015). Statistik Untuk Bisnis dan Ekonomi. Pustaka Baru Express. Sunarto, R. (2015). Pengantar Statistika Untuk Penelitian: Pendidikan, Sosial, Komunikasi, Ekonomi, dan Bisnis. Alfabeta.

Sutrisno, H. E. (2009). Manajemen Sumber Daya Manusia (Edisi 1). Prenamedia Group.

Swasto, B. (2011). Manajemen Sumber Daya Manusia. UB Press.

Usman, H. (2013). Manajemen Teori, Praktik, dan Riset Pendidikan. Edisi, 4. Widodo, S. E. (2015). Manajemen Pengembangan Sumber Daya Manusia. Pustaka Pelajar. 